Ariyanti, M. • M.A. Soleh • Y. Maxiselly

\title{
Respon pertumbuhan tanaman aren (Arenga pinnata merr.) dengan pemberian pupuk organik dan pupuk anorganik berbeda dosis
}

\section{Response of sugarpalm (Arenga pinnata merr.) growth by different dosage treatment of organic and anorganic fertilizer}

Diterima : 15 Februari 2017/Disetujui : 15 Maret 2017 / Dipublikasikan : 30 Maret 2017

CDepartment of Crop Science, Padjadjaran University

\begin{abstract}
Sugar palm (Arenga pinnata Merr.) is one of plantation crops that has high economic value and is potential to be developed. One effort to increase the productivity of palm in Indonesia is by fertilizing. Common inorganic fertilizers applied to the sugar plant has a tendency to damage the quality of the soil. Therefore, it is necessary to attempt to restore the health of the soil by way counterbalance inorganic fertilizer with organic fertilizer. This research was conducted at the experimental field Ciparanje, Faculty of Agriculture, University of Padjadjaran, Jatinangor, Sumedang regency, West Java, in October 2016. The research design model was the form of a randomized block design (RBD), consisting of six combination treatments and repeated four times. Each experimental unit consisted of one plant so that the total plant consists of 24 plants. The treatments given to the sugar palm were: I (without fertilizer); II (organic fertilizer 100\%) (9 kg / seedling/ year); III (inorganic fertilizer 100\%); IV $25 \%+75 \%$ organic fertilizer inorganic fertilizer; $\mathrm{V}$ $(50 \%+50 \%$ organic fertilizer inorganic fertilizers); and VI $(75 \%+25 \%$ organic fertilizer inorganic fertilizer). Furthermore, it was conducted an analysis of variance by $\mathrm{F}$ test level of $5 \%$. Least Significance Difference (LSD) test at level of 5\% would be conducted if there were differences among the treatments. The results showed that the addition of $25 \%$ to $50 \%$ organic fertilizer combined with $50 \%-75 \%$ inorganic fertilizer influential good on the growth immature plant of sugar palm especially on the the average increase plant height, the average increase stem girth and the average the growing leaf number parameters .
\end{abstract}

\footnotetext{
Dikomunikasikan oleh Agus Wahyudin

Ariyanti, M. ${ }^{1} \cdot$ M.A. Soleh ${ }^{1} \cdot$ Y. Maxiselly ${ }^{1}$

1) Departemen Budidaya Pertanian, Fakultas Pertanian,

Universitas Padjadjaran. Jl. Raya Bandung-Sumedang

$\mathrm{km} .21$, Jatinangor, Jawa Barat, Indonesia

Korespondensi:mira.ariyanti@unpad.ac.id
}

Keywords: Inorganic fertilizer • Organic fertilizer · Sugar palm

Sari Tanaman aren (Arenga pinnata Merr.) adalah salah satu tanaman perkebunan yang bernilai ekonomis tinggi dan potensial untuk terus dikembangkan. Salah satu upaya untuk meningkatkan produktivitas aren di Indonesia adalah dengan pemupukan. Pupuk anorganik yang lazim diaplikasikan pada tanaman aren memiliki kecenderungan untuk merusak kualitas tanah. Karena itu, perlu dilakukan usaha untuk mengembalikan kesehatan tanah dengan cara mengimbangi pemberian pupuk anorganik dengan pupuk organik. Penelitian ini dilakukan di kebun percobaan Ciparanje, Fakultas Pertanian Universitas Padjadjaran, Kecamatan Jatinangor Kabupaten Sumedang, Jawa Barat pada Oktober 2016 - Desember 2016. Penelitian menggunakan rancangan acak kelompok terdiri dari enam kombinasi perlakuan dan diulang sebanyak empat kali. Perlakuan meliputi tanpa pupuk, pupuk organik $100 \%$, pupuk anorganik $100 \%, 25 \%$ pupuk organik $+75 \%$ pupuk anorganik, 50\% pupuk organik $+50 \%$ pupuk anorganik, dan 75\% pupuk organik $+25 \%$ pupuk anorganik. Hasil penelitian menunjukkan bahwa penambahan $25 \%-50 \%$ pupuk organik yang dikombinasikan dengan $50 \%-75 \%$ pupuk anorganik berpengaruh baik terhadap pertumbuhan aren TBM terutama pada parameter rata-rata pertambahan tinggi tanaman, rata-rata pertambahan lilit batang dan jumlah daun.

Kata Kunci : Aren · Pupuk anorganik · Pupuk organik 


\section{Pendahuluan}

Aren (Arenga pinnata Merr.) termasuk salah satu jenis tanaman palma, yang tersebar hampir di seluruh wilayah Indonesia, terutama di 14 provinsi, yaitu Papua, Maluku, Maluku Utara, Sumatera Utara, Sumatera Barat, Jawa Barat, Jawa Tengah, Banten, Sulawesi Utara, Sulawesi Selatan, Sulawesi Tenggara, Bengkulu, Kalimantan Selatan dan Aceh. Tanaman aren (Arenga pinnata Merr.) adalah tanaman perkebunan yang sangat potensial untuk dikembangkan dan mudah beradaptasi baik pada berbagai agroklimat, mulai dari dataran rendah hingga $1400 \mathrm{~m}$ di atas permukaan laut (Efendi dan Soleh, 2010).

Salah satu upaya untuk meningkatkan produktivitas aren di Indonesia adalah dengan memperhatikan usaha budidaya aren, salah satunya pemupukan. Pemupukan perlu dilakukan karena kandungan unsur hara dalam tanah bervariasi dan berubah-ubah disebabkan terjadinya kehilangan unsur hara melalui pencucian. Pemupukan diharapkan meningkatkan produktivitas, mendukung pembangunan perkebunan dan rehabilitasi tanaman aren. Pemupukan aren tidak hanya diaplikasikan pada tanaman menghasilkan (TM) tetapi juga pada tanaman belum menghasilkan (TBM). Aren TBM yang dipupuk pertumbuhan dan perkembangannya lebih baik dibandingkan dengan tanaman yang tidak dipupuk. Pupuk yang diaplikasikan pada tanaman aren adalah pupuk organik dan pupuk anorganik. Pemberian pupuk organik dapat memperbaiki struktur tanah, meningkatkan daya simpan air, memperbaiki kondisi kehidupan mikroba tanah dan sebagai sumber makanan bagi tanaman. Pemberian pupuk anorganik dapat merangsang pertumbuhan tanaman secara keseluruhan dan sebagai bahan pembentukan klorofil (Mashud, dkk., 2013).

Dewasa ini penggunaan pupuk anorganik cenderung berlebihan yang mengakibatkan tanah mengalami pencemaran dan penurunan kualitas. Karena itu diupayakan pengaplikasian pupuk organik yang memiliki manfaat menjaga atau memperbaiki kualitas tanah. Perlu adanya perimbangan penggunaan pupuk organik dan anorganik. Pada aren TBM, pemupukan pupuk organik 100\% memberikan hasil pertumbuhan vegetatif yang terbaik (Mashud, dkk., 2013). Menurut Hayati, dkk (2011), pemupukan 50\% organik $+50 \%$ anorganik tidak berbeda nyata dengan perlakuan $100 \%$ organik, yaitu berpengaruh nyata terhadap berat tongkol dan kelobot tanaman jagung. Pada tanaman padi, perlakuan pupuk organik 25\% + pupuk anorganik $75 \%$ menghasilkan berat gabah kering panen tertinggi (Hartati, dkk., 2014).

Penelitian ini bertujuan untuk memperoleh dosis pemupukan dan jenis pupuk yang berpengaruh terbaik terhadap pertumbuhan tanaman aren. Penelitian ini juga bertujuan untuk membandingkan pola pertumbuhan tanaman aren akibat dosis pemupukan dan jenis pupuk, sehingga nantinya dapat mengurangi penggunaan pupuk anorganik.

\section{Bahan dan Metode}

Percobaan dilakukan di kebun percobaan Ciparanje, Fakultas Pertanian Universitas Padjadjaran, kecamatan Jatinangor, kabupaten Sumedang, Jawa Barat yang berada pada ketinggian tempat $\pm 725 \mathrm{~m}$ dpl. Jenis tanah yang digunakan yaitu Inceptisol. Curah hujan tipe C (Schmidt dan Ferguson, 1951). Waktu percobaan dilaksanakan bulan Oktober-Desember 2106. Bahan tanam yang digunakan adalah tanaman aren berumur 3 tahun. Pupuk anorganik NPK Mutiara, pupuk organik kompos.

Percobaan ini menggunakan Rancangan Acak Kelompok (RAK) yang terdiri dari enam kombinasi perlakuan dan diulang sebanyak empat kali. Perlakuan percobaan terdiri dari tanpa pupuk, pupuk organik 100\%, pupuk anorganik 100\%, 25\% pupuk organik $+75 \%$ pupuk anorganik, 50\% pupuk organik $+50 \%$ pupuk anorganik, 75\% pupuk organik $+25 \%$ pupuk anorganik.

Peubah yang diamati adalah pertumbuhan vegetatif dan pembuahan tanaman aren meliputi pertambahan tinggi tanaman, pertambahan lilit batang, jumlah daun, pertambahan luas daun, pertambahan luas kanopi.

\section{Hasil dan Pembahasan}

Rata-rata Pertambahan Tinggi Tanaman. Tabel 1 menunjukkan bahwa pemberian kombinasi pupuk organik dan organik masingmasing 50\% (perlakuan E) menghasilkan ratarata pertambahan tinggi tanaman aren terbaik dibandingkan perlakuan lain pada 1 BSP - 3 BSP 
(bulan setelah perlakuan). Pada 3 BSP terutama pengaruhnya terhadap rata-rata pertambahan tinggi tanaman aren, pemberian pupuk anorganik dapat dikurangi sebanyak 50\% dan sebagian kekurangan unsur hara tanaman digantikan dari pupuk organik. Selain itu dosis pupuk yang terdiri dari 50\% pupuk organik + $50 \%$ pupuk anorganik merupakan perbandingan persentase pemupukan yang baik dimana dengan pemberian $50 \%$ pupuk organik dapat memperbaiki struktur tanah yang pada akhirnya diharapkan meningkatkan penyerapan unsur hara yang terkandung dalam pupuk anorganik.

Penggunaan pupuk organik bukanlah dimaksudkan untuk menggantikan penggunaan pupuk anorganik seluruhnya, melainkan untuk meningkatkan efisiensi serapan hara dari pupuk anorganik. Quansah (2010) menyatakan bahwa kombinasi antara pupuk anorganik dengan organik umumnya lebih meningkatkan pertumbuhan karena bahan organik dapat memperbaiki kondisi tanah sehingga unsur hara lebih tersedia untuk tanaman.

Tabel 1. Pengaruh Pemberian Pupuk Organik dan Pupuk Anorganik terhadap Rata-rata Pertambahan Tinggi Tanaman Aren Umur 1, 2, 3 BSP

\begin{tabular}{ccrc}
\hline \hline \multirow{2}{*}{$\begin{array}{c}\text { Perla- } \\
\text { kuan }\end{array}$} & \multicolumn{3}{c}{ Rata-rata Pertambahan Tinggi Tanaman } \\
& \multicolumn{3}{c}{$(\mathbf{c m})$} \\
\hline & $\mathbf{1 ~ B S P}$ & $\mathbf{2 ~ B S P}$ & \multicolumn{1}{c}{ 3 BSP } \\
\hline $\mathrm{A}$ & $6,31 \mathrm{bc}$ & $15,49 \mathrm{~b}$ & $23,73 \mathrm{Ab}$ \\
$\mathrm{B}$ & $1,15 \mathrm{c}$ & $4,64 \mathrm{~b}$ & $9,10 \mathrm{Bc}$ \\
$\mathrm{C}$ & $12,00 \mathrm{~b}$ & $17,63 \mathrm{~b}$ & $22,57 \mathrm{Ab}$ \\
$\mathrm{D}$ & $5,73 \mathrm{bc}$ & $7,62 \mathrm{~b}$ & $8,79 \mathrm{Bc}$ \\
$\mathrm{E}$ & $23,19 \mathrm{a}$ & $31,22 \mathrm{a}$ & $35,73 \mathrm{~A}$ \\
$\mathrm{~F}$ & $3,24 \mathrm{bc}$ & $4,83 \mathrm{~b}$ & $6,85 \mathrm{C}$ \\
\hline \hline
\end{tabular}

Keterangan : BSP = bulan setelah perlakuan Angka-angka pada kolom yang sama yang diikuti oleh huruf yang sama tidak berbeda nyata berdasarkan uji Duncan a 0.05.

Quansah (2010) menyatakan bahwa kombinasi antara pupuk anorganik dengan organik umumnya lebih meningkatkan pertumbuhan karena bahan organik dapat memperbaiki kondisi tanah sehingga unsur hara lebih tersedia untuk tanaman. Herviyanti, dkk (2012) dalam Siallagan, dkk (2014) menyatakan bahwa tanahtanah dengan kandungan bahan organik tinggi dapat meningkatkan KTK tanah dan mampu mengikat unsur hara, sehingga efektivitas pemupukan anorganik juga meningkat. Aplikasi pupuk organik juga dapat digunakan tanaman untuk jangka panjang dan diserap secara perlahan (Ermadani dan Muzar, 2011) dalam Siallagan, dkk (2014).

Pada Tabel 1 terlihat bahwa rata-rata pertambahan tinggi tanaman aren pada 3 BSP dengan pemberian pupuk organik dan anorganik masing-masing 50\% (perlakuan E) tidak berbeda nyata dengan perlakuan 100\% pupuk anorganik (perlakuan C). Kenyataannya tidak demikian, dimana perlakuan $\mathrm{E}$ menghasilkan tanaman aren tertinggi dibandingkan perlakuan lainnya (Gambar 1). Pada tanah yang tidak dipupuk diduga bahwa pada tanah tersebut masih terkandung unsur hara yang mampu menyokong kebutuhan unsur hara tanaman sampai dengan 3 BSP tetapi pada akhirnya tetap diperlukan penambahan unsur hara terutama yang berasal dari pupuk organik. Pupuk organik memiliki sifat tersedia lambat tapi keberadaannya dapat menjadikan tanah lebih awet. Herviyanti, dkk (2012) menyatakan bahwa tanah-tanah dengan kandungan bahan organik tinggi dapat meningkatkan KTK tanah dan mampu mengikat unsur hara, sehingga efektivitas pemupukan anorganik juga meningkat. Aplikasi pupuk organik juga dapat digunakan tanaman untuk jangka panjang dan diserap secara perlahan (Ermadani dan Muzar, 2011).

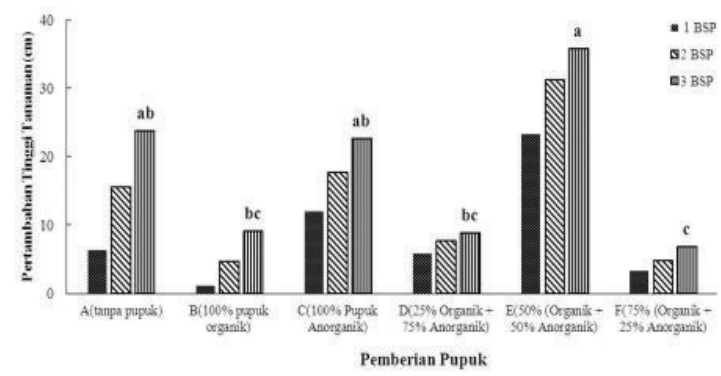

Gambar 1. Rata-rata pertambahan tinggi tanaman aren dengan pemberian pupuk organik dan anorganik berbeda dosis pada 1 BSP - 3 BSP

Ketersediaan hara $(\mathrm{N}$ dan $\mathrm{P})$ pada tanaman yang dipupuk dengan kombinasi $50 \%$ organik + $50 \%$ anorganik tersebut optimal dan mudah untuk diserap oleh akar sehingga berpengaruh terhadap tinggi bibit tanaman aren. Hal ini disebabkan juga karena pupuk organik mampu memperbaiki sifat fisik, kimia dan biologi tanah, serta mampu menyediakan senyawa karbon yang berfungsi memperbaiki sifat fisik dan biologi tanah (Setyorini, dkk, 2006). 
Selain itu pertumbuhan tanaman dipengaruhi pula oleh faktor lain selain pemupukan diantaranya faktor genetik, unsur hara, sinar matahari, kelembaban dan lain-lain (Manahan, 2014). Pertumbuhan tanaman dipengaruhi oleh dua faktor penting yaitu faktor genetis dan faktor lingkungan. Faktor genetik sangat menentukan kemampuan tanaman untuk memberikan produksi yang tinggi serta sifat penting lainnya seperti kualitas hasil, ketahanan terhadap serangan hama dan penyakit, kekeringan dan lain-lain. Faktor lingkungan yang mempengaruhi kehidupan dan perkembangan tanaman antara lain: temperatur, kelembaban, sinar matahari, susunan atmosfir, struktur tanah, reaksi tanah $(\mathrm{pH})$, dan faktor biotik.

Rata-rata Pertambahan Lilit Batang. Pertambahan lilit batang menggambarkan pertumbuhan tanaman dalam hal pertumbuhan batang sebagai salah satu organ yang berperan dalam menopang kemampuan tegak dan menancap kuatnya tanaman pada media tanam. Pertumbuhan batanag yang baik akan menyebabkan tanaman tidak mudah roboh seiring dengan meningginya tanaman. Keadaan proporsional antara pertumbuhan meninggi dan melebarnya batang tanaman menjadi faktor penting dalam keberlangsungan hidup tanaman, dalam hal ini tidak mudah robohnya tanaman ketika angin bertiup kencang.

Tabel 2. Pengaruh Pemberian Pupuk Organik dan Pupuk Anorganik terhadap Rata-rata Pertambahan Lilit Batang Tanaman Aren Umur 1, 2, 3 BSP

\begin{tabular}{|c|c|c|c|c|c|c|}
\hline \multirow{2}{*}{$\begin{array}{l}\text { Perlak } \\
\text { uan }\end{array}$} & \multicolumn{6}{|c|}{$\begin{array}{l}\text { Rata-rata Pertambahan Lilit Batang } \\
\qquad(\mathrm{cm})\end{array}$} \\
\hline & $1 \mathrm{BSP}$ & & $2 \mathrm{BS}$ & & $3 \mathrm{~B}$ & \\
\hline A & 0,34 & $a$ & 0,43 & $\mathrm{~b}$ & 0,49 & $b$ \\
\hline B & 0,92 & a & 1,93 & a & 2,77 & $\mathrm{a}$ \\
\hline $\mathrm{C}$ & 0,59 & a & 1,21 & a & 1,80 & a \\
\hline $\mathrm{D}$ & 0,45 & a & 1,95 & a & 2,72 & a \\
\hline E & 0,28 & $\mathrm{a}$ & 0,79 & $b$ & 1,29 & a \\
\hline F & 0,56 & a & 1,14 & $\mathrm{a}$ & 1,99 & a \\
\hline
\end{tabular}

Keterangan : BSP = bulan setelah perlakuan Angka-angka pada kolom yang sama yang diikuti oleh huruf yang sama tidak berbeda nyata berdasarkan uji Duncan a 0.05.

Rata-rata pertambahan lilit batang tanaman aren memperlihatkan perbedaan yang nyata antara perlakuan pemberian pupuk mulai pada 2 BSP. Pada 3 BSP terlihat pengaruh pemberian pupuk baik organik maupun anorganik dibandingkan dengan tanaman yang tidak dipupuk. Hal ini menunjukkan bahwa pupuk berperan penting dalam pertumbuhan tanaman.

Gambar 2 menunjukkan bahwa pemberian $25 \%$ pupuk organik yang ditambahkan $75 \%$ pupuk anorganik (perlakuan D) menghasilkan rata-rata pertambahan lilit batang tanaman aren yang hampir sama dengan tanaman aren yang dipupuk $100 \%$ pupuk anorganik (perlakuan C). Hal ini berarti bahwa pemberian pupuk anorganik dapat dikurangi sebesar 25\% untuk menghasilkan pertumbuhan lilit batang aren yang setara dengan pertumbuhan lilit batang tanaman aren yang diberi 100\% pupuk anorganik.

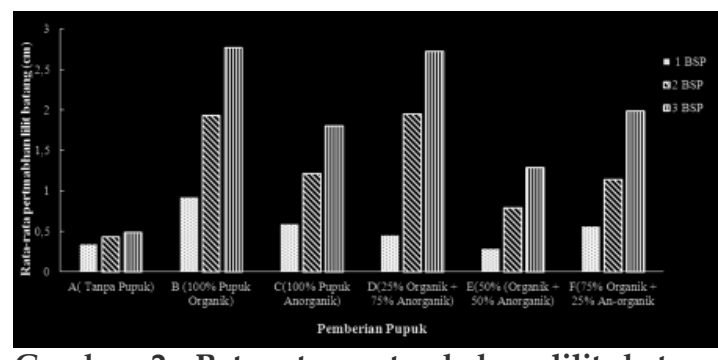

Gambar 2. Rata-rata pertambahan lilit batang tanaman aren dengan pemberian pupuk organik dan organik berbeda dosis pada 1 bulan setelah perlakuan (BSP) - 3 BSP

Rata-rata pertambahan lilit batang aren lebih cepat pada 1 BSP - 2 BSP dengan diberikannya perlakuan D dibandingkan perlakuan A (Gambar 2). Keadaan ini menunjukkan bahwa pada 1 BSP, bahan organik yang dikandung pupuk organik mulai berkontribusi dalam menyuplai unsur hara dan kemungkinan mulai berperan dalam memperbaiki sifat fisik tanah sehingga tercipta kondisi yang baik bagi pertumbuhan tanaman aren. Pertumbuhan lilit batang dan tinggi tanaman termasuk komponen pertumbuhan vegetatif sehingga dalam hal pengaruh pemupukan yang diberikan, pengurangan penggunaan pupuk anorganik sebesar 25 - 50\% yang digantikan dengan pupuk organik merupakan langkah baik dilihat dari pertumbuhan tanaman tersebut yang setara dengan aplikasi pupuk anorganik 100\%.

Rata-rata Pertambahan Luas Daun. Tabel 3 menunjukkan bahwa pemberian $100 \%$ pupuk anorganik (perlakuan C) menghasilkan rata-rata pertambahan luas daun tertinggi dibandingkan perlakuan pemberian pupuk lainnya terutama pada 2 BSP dan 3 BSP. Pada 1 BSP pemberian 
$100 \%$ pupuk anorganik menghasilkan rata-rata pertambahan luas daun tanaman aren yang tidak berbeda dengan pemberian pupuk organik baik pada taraf $25 \%, 50 \%$ dan $100 \%$. Hal ini berkaitan dengan unsur $\mathrm{N}$ yang dikandung pupuk anorganik lebih tinggi dibandingkan yang dikandung pupuk organik. Disamping itu dapat pula dikaitkan dengan sifat pupuk organik yang lambat tersedia sehingga tidak begitu berkontribusi dalam penyediaan unsur hara terutama $\mathrm{N}$ pada saat tanaman aren membutuhkan unsur tersebut untuk pertumbuhan luas daun.

Tabel 3. Pengaruh Pemberian Pupuk Organik dan Pupuk Anorganik terhadap Luas Daun Tanaman Aren Umur 1, 2, 3 BSP

\begin{tabular}{ccrc}
\hline \hline \multirow{2}{*}{$\begin{array}{c}\text { Perla- } \\
\text { kuan }\end{array}$} & \multicolumn{3}{c}{ Rata-rata Pertambahan Luas Daun $\left.\mathbf{( c m}^{2}\right)$} \\
\cline { 2 - 4 } & 1 BSP & 2 BSP & 3 BSP \\
\hline $\mathrm{A}$ & $263,09 \mathrm{~b}$ & $830,14 \mathrm{~b}$ & $1373,88 \mathrm{~b}$ \\
$\mathrm{~B}$ & $1188,71 \mathrm{a}$ & $1657,90 \mathrm{~b}$ & $1921,85 \mathrm{~b}$ \\
$\mathrm{C}$ & $1415,73 \mathrm{a}$ & $3699,55 \mathrm{a}$ & $8502,55 \mathrm{a}$ \\
$\mathrm{D}$ & $728,33 \mathrm{ab}$ & $1106,20 \mathrm{~b}$ & $1372,28 \mathrm{~b}$ \\
$\mathrm{E}$ & $669,81 \mathrm{ab}$ & $1097,89 \mathrm{~b}$ & $1518,97 \mathrm{~b}$ \\
$\mathrm{~F}$ & $162,01 \mathrm{~b}$ & $423,21 \mathrm{~b}$ & $1186,46 \mathrm{~b}$ \\
\hline \hline
\end{tabular}

Keterangan : BSP = bulan setelah perlakuan Angka-angka pada kolom yang sama yang diikuti oleh huruf yang sama tidak berbeda nyata berdasarkan uji Duncan a 0.05.

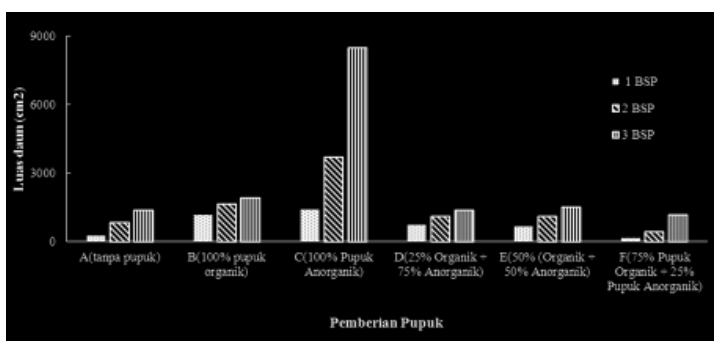

Gambar 3. Luas daun tanaman aren dengan pemberian pupuk organik dan anorganik berbeda dosis pada 1 BSP - 3 BSP

Pemupukan dengan 100\% pupuk anorganik menghasilkan daun tanaman aren terluas dibandingkan komposisi pemupukan lainnya pada 2 BSP dan 3 BSP (Gambar 3). Menurut Pradnyawan, dkk (2005), unsur N berperan dalam sintesis protein dan asam nukleat dalam sel yang berperan dalam pembentukan sel baru sebagai indikator pertumbuhan tanaman. Darmawan (2006) menyatakan pemberian nitrogen dosis tinggi dapat meningkatkan laju fotosintesis tanaman sehingga meningkatkan pertumbuhan tanaman yang nantinya akan berpengaruh terhadap luas daun tanaman.

Lindawati, dkk. (2000) menyatakan bahwa $\mathrm{N}$ diperlukan untuk memproduksi protein, lemak, dan berbagai persenyawaan organik lainnya. $\mathrm{N}$ penting dalam hal pembentukan hijau daun yang berguna sekali dalam proses fotosintesis. Fotosintat yang dihasilkan akan dirombak kembali melalui proses respirasi dan menghasilkan energi yang diperlukan oleh sel untuk melakukan aktivitas seperti pembelahan dan pembesaran sel yang terdapat pada daun tanaman yang menyebabkan daun mencapai panjang dan lebar maksimal (Sitompul, dkk, 2014).

Jumlah Daun Tanaman Aren. Pada kenyataannya pertanaman aren merupakan tanaman hutan yang tidak banyak dilakukan tindakan budidaya diantaranya pemupukan dalam arti bahwa tanaman ini tumbuh pada tanah yang dengan kondisi unsur hara yang relatif. Pada masa TBM sebenarnya tanaman aren memerlukan unsur hara yang cukup untuk menjamin pertumbuhan dan perkembangan tanaman pada masa TM. Jumlah daun dapat dijadikan indikator bagaimana pertumbuhan tanaman aren pada masa TBM, karena dengan adanya jumlah daun yang cukup diharapkan tanaman dapat melakukan fotosintesis yang optimal yang pada akhirnya akan berpengaruh baik bagi pertumbuhan tanaman aren.

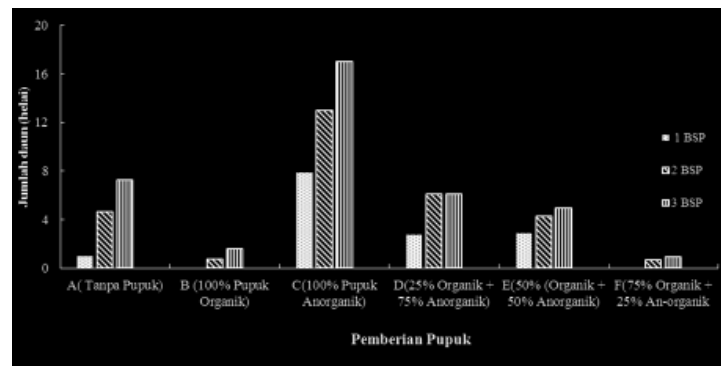

Gambar 4. Jumlah daun tanaman aren dengan pemberian pupuk organik dan anorganik berbeda dosis pada 1 bulan setelah perlakuan (BSP) - 3 BSP

Gambar 4 menunjukkan bahwa pemberian $100 \%$ pupuk anorganik (perlakuan C) menghasilkan jumlah daun terbanyak dibandingkan perlakuan pemupukan lainnya. Hal ini disebabkan pertumbuhan tunas-tunas menjadi daun lebih banyak memerlukan unsur $\mathrm{N}$ dan kandungan $\mathrm{N}$ dalam pupuk anorganik lebih tinggi dibandingkan pupuk organik. Menurut Pradnyawan, dkk (2005) unsur N berperan 
dalam sintesis protein dan asam nukleat dalam sel yang berperan dalam pembentukan sel baru sebagai indikator pertumbuhan tanaman. Darmawan (2006) menyatakan pemberian nitrogen dosis tinggi dapat meningkatkan laju fotosintesis tanaman sehingga meningkatkan pertumbuhan tanaman yang nantinya akan berpengaruh terhadap luas daun tanaman.

Tabel 4. Pengaruh Pemberian Pupuk Organik dan Pupuk Anorganik terhadap Jumlah Daun Tanaman Aren Umur 1, 2, 3 BSP

\begin{tabular}{cccc}
\hline \multirow{2}{*}{ Perlakuan } & \multicolumn{3}{c}{ Jumlah Daun (helai) } \\
\cline { 2 - 4 } & 1 BSP & 2 BSP & 3 BSP \\
\hline $\mathrm{A}$ & $1,00 \mathrm{~b}$ & $4,63 \mathrm{ab}$ & $7,25 \mathrm{ab}$ \\
$\mathrm{B}$ & $0,00 \mathrm{~b}$ & $0,75 \mathrm{~b}$ & $1,58 \mathrm{~b}$ \\
$\mathrm{C}$ & $7,88 \mathrm{a}$ & $13,00 \mathrm{a}$ & $17,04 \mathrm{a}$ \\
$\mathrm{D}$ & $2,75 \mathrm{~b}$ & $6,13 \mathrm{ab}$ & $6,09 \mathrm{ab}$ \\
$\mathrm{E}$ & $2,88 \mathrm{~b}$ & $4,31 \mathrm{ab}$ & $4,96 \mathrm{~b}$ \\
$\mathrm{~F}$ & $0,00 \mathrm{~b}$ & $0,69 \mathrm{~b}$ & $0,96 \mathrm{~b}$ \\
\hline \hline
\end{tabular}

Keterangan : BSP = bulan setelah perlakuan

Angka-angka pada kolom yang sama yang diikuti oleh huruf yang sama tidak berbeda nyata berdasarkan uji Duncan a 0.05 .

Pemberian pupuk tetap dibutuhkan oleh tanaman mengingat bahwa unsur hara dalam tanah akan semakin berkurang bahkan terkuras apabila tidak ada usaha dalam mengembalikan kesuburan tanah terlebih apabila tanaman yang tumbuh di atasnya merupakan tanaman tahu-nan termasuk aren yang banyak memerlukan suplai unsur hara dibanding tanaman semusim. Pada Gambar 4 terlihat pada perlakuan pemberian 100 $\%$ pupuk anorganik menghasilkan jumlah daun yang lebih banyka dibandingkan perlakuan pemberian pupuk organik, tetapi dalam hal ini tetap diperlukan informasi pemupukan yang berkaitan dengan kebutuhan pupuk baik organik maupun anorganik untuk menunjang pertumbuhan dan perkembangan tanaman. Pemupukan dengan 25\% pupuk organik $+75 \%$ pupuk anorganik (perlakuan D) merupakan kombinasi pemupukan yang baik untuk mengurangi penggunaan pupuk anorganik yang apabila diaplikasikan secara terus-menerus akan menurunkan kualitas tanah. Pupuk organik memiliki unsur hara makro dan mikro yang lengkap namun jumlahnya relatif kecil (Setyorini, dkk. 2006)

Luas Kanopi Tanaman Aren. Tabel 5 menunjukkan bahwa pemberian pupuk organik dan pupuk anorganik berbeda dosis berpengaruh nyata terhadap luas kanopi tanaman aren pada 1 BSP, 2 BSP dan 3 BSP. Pemberian $100 \%$ pupuk anorganik menghasilkan luas kanopi yang terlebar dibandingkan perlakuan yang lain (Gambar 5). Menurut Novrian (2005), unsur $\mathrm{N}$ dibutuhkan dalam jumlah relatif besar pada setiap pertumbuhan, terutama pertumbuhan vegetatif seperti pertumbuhan luas kanopi dan pembentukkan tunas.

Tabel 5. Pengaruh Pemberian Pupuk Organik dan Pupuk Anorganik terhadap Luas Kanopi Tanaman Aren Umur 1, 2, 3 BSP

\begin{tabular}{crrr}
\hline \hline \multirow{2}{*}{ Perlakuan } & \multicolumn{3}{c}{ Pertambahan Luas Kanopi Tanaman } \\
Aren $\left.\mathbf{( c m}^{2}\right)$ \\
\cline { 2 - 4 } & \multicolumn{1}{c}{ 1 BSP } & \multicolumn{1}{c}{ 2 BSP } & \multicolumn{1}{c}{ 3 BSP } \\
\hline A & $324,38 \mathrm{~b}$ & $641,07 \mathrm{~b}$ & $942,19 \mathrm{~b}$ \\
$\mathrm{~B}$ & $714,56 \mathrm{~b}$ & $1554,45 \mathrm{~b}$ & $2525,34 \mathrm{~b}$ \\
$\mathrm{C}$ & $25552,90 \mathrm{a}$ & $18179,22 \mathrm{a}$ & $16837,09 \mathrm{a}$ \\
$\mathrm{D}$ & $1783,23 \mathrm{~b}$ & $2314,25 \mathrm{~b}$ & $2198,50 \mathrm{~b}$ \\
E & $1467,31 \mathrm{~b}$ & $2425,63 \mathrm{~b}$ & $3170,54 \mathrm{~b}$ \\
F & $1699,31 \mathrm{~b}$ & $2669,03 \mathrm{~b}$ & $4101,73 \mathrm{~b}$ \\
\hline \hline
\end{tabular}

Keterangan : BSP = bulan setelah perlakuan Angka-angka pada kolom yang sama yang diikuti oleh huruf yang sama tidak berbeda nyata berdasarkan uji Duncan a 0.05 .

Pemberian 100\% pupuk anorganik dimana kandungan unsur haranya cukup memenuhi kebutuhan tanaman sehingga memungkinkan tajuk tanaman tumbuh lebih lebar. Unsur hara yang diberikan pada tanaman melalui pupuk anorganik relatif lebih cepat tersedia di dalam tanah (Barus, 2011) dan lebih cepat diserap akar tanaman. Unsur hara N, P, dan K merupakan unsur hara yang paling banyak dibutuhkan oleh tanaman dan apabila terjadi kekurangan unsur tersebut akan menyebabkan menurunnya aktivitas pertumbuhan tanaman (Mashud, dkk.,2013). Menurut Manahan, dkk (2014), hal ini dikarenakan pupuk organik diperlukan dalam jumlah yang banyak untuk dapat memenuhi kebutuhan unsur hara.

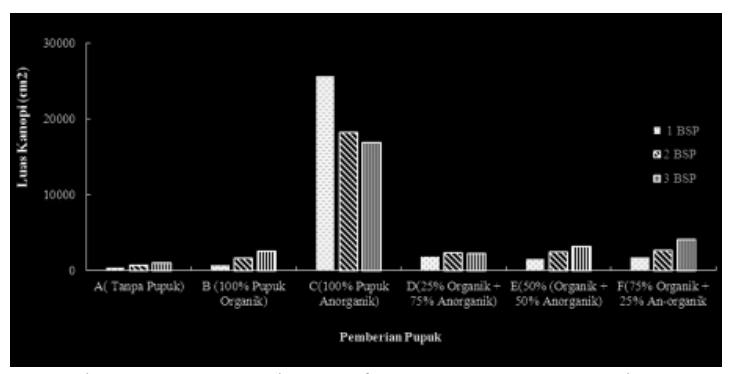

Gambar 5. Luas kanopi tanaman aren dengan pemberian pupuk organik dan anorganik berbeda dosis pada 1 BSP - 3 BSP 
Luas kanopi tanaman selain dipengaruhi oleh unsur hara juga dipengaruhi oleh faktor iklim seperti intesitas cahaya matahari sehingga terdapat kaitannya dengan jarak tanam yang digunakan. Lebih lebar jarak tanam yang digunakan maka tanaman akan lebih memiliki ruang tumbuh lebih luas sehingga pertumbuhan tajuk tanaman cenderung lebih luas.

\section{Kesimpulan}

Pemupukan merupakan hal penting dalam menunjang pertumbuhan dan perkembangan tanaman aren. Aplikasi pupuk anorganik secara terus-menerus dapat menyebabkan kerusakan tanah yang mengakibatkan berkurangnya daya dukung tanah sebagai media tanam khususnya tanaman aren sebagai salah satu tanaman perkebunan yang cukup potensial untuk dikembangkan. Pengurangan dosis pupuk anorganik dan digantikan dengan dosis pupuk organik sejauh ini memungkinkan untuk diaplikasi pada tanaman aren TBM. Penambahan 25-50 \% pupuk organik yang dikombinasikan dengan 50-75\% pupuk anorganik berpengaruh baik terhadap pertumbuhan aren TBM terutama pada parameter rata-rata pertambahan tinggi tanaman, rata-rata pertambahan lilit batang dan rata-rata pertambahan jumlah daun.

\section{Ucapan Terıma Kasıh}

Ucapan terima kasih kepada mahasiswa dan mahasiswi minat perkebunan angkatan 2013 dan 2014, Departemen Budidaya Pertanian, Fakultas Pertanian, Universitas Padjadjaran yang telah membantu dalam pelaksanaan penelitian ini.

\section{Daftar Pustaka}

Barus. A. A. 2011. Pemanfaatan Pupuk Cair Mikro Untuk Meningkatkan Pertumbuhan dan Produksi Tanaman Sawi (Brassica juncea L.) Varietas Tosakan. Skripsi. Universitas Sumatera Utara.

Darmawan, 2006. Perbaikan pertumbuhan bibit kelapa sawit melalui aplikasi pupuk daun dengan nitrogen. Jurnal Buletin Penelitian, 9 (1): 36-42
Efendi, Dedi Soleh. 2010. Prospek Pengembangan Tanaman Aren (Arenga pinnata Merr) Mendukung Kebutuhan Bioetanol di Indonesia. Perspektif Vol. 9 No. 1 / Juni: $36-46$.

Ermadani, A. Muzar. 2011. Pengaruh aplikasi limbah cair pabrik kelapa sawit terhadap hasil kedelai dan perubahan sifat kimia tanah Ultisol. J. Agron. Indonesia 39:160167.

Hartati. S.. Sumani.. H.E.A Hendrata. 2014. Pengaruh Imbangan Pupuk Organik dan Anorganik terhadap Serapan P dan Hasil Tanaman Padi Sawah pada Dua Sistem Budidaya di Lahan Sawah Sukoharjo. Jurnal Ilmu Ilmu Pertanian Vol. XXIX No. 1 Tersedia: download. portalgaruda.org. Diakses pada 1 November 2016.

Hayati. M.. E. Hayati.. D. Nurfandi. 2011. Pengaruh Pupuk Organik dan Anorganik terhadap Pertumbuhan beberapa Varietas Jagung Manis di Lahan Tsunami. J. Floratek 6: 74-83. Tersedia: jurnal.unsyiah. ac.id. Diakses pada 1 November 2016.

Herviyanti, A. Fachri, S. Riza, Darmawan, Gusnidar, S. Amrizal. 2012. Pengaruh pemberian bahan humat dan pupuk P pada Ultisol. J. Solum 19:15-24.

Lindawati, N., Izhar dan H. Syafria. 2000. Pengaruh pemupukan nitrogen dan interval pemotongan terhadap produktivitas dan kualitas rumput lokal kumpai pada tanah podzolik merah kuning. JPPTP 2(2): 130-133.

Manahan, L.A.P. Putri, dan Y. Husni. 2014. Respons pertumbuhan bibit aren (Arenga pinnata Merr.) terhadap pemberian pupuk organik cair. Jurnal Online Agroteknologi 2 (2) : 460 - 471. Tersedia : jurnal.usu.ac.id (Diakses tanggal 12 Desember 2016)

Mashud, N., R.B. Maliangkay, dan M. Nur. 2013. Pengaruh pemupukan terhadap pertumbuhan vegetatif tanaman aren belum menghasilkan. Buletin Palma 14 (1) : 13 19. Tersedia : ejurnal.litbang.pertanian. go.id (Diakses tanggal 12 Desember 2016).

Mashud. N.. R.B. Maliangkay. M. Nur. 2013. Pengaruh Pemupukan terhadap Pertumbuhan Vegetatif Tanaman Aren Belum Menghasilkan. B. Palma Vol. 14 (1) : 13-19. Tersedia: ejurnal.litbang.pertanian. go.id. Diakses pada 31 Oktober 2016.

Novrian. 2005. Petunjuk Pemupukan Efektif. Agromedia Pustaka. Depok. Hal 15-35. 
Pradnyawan, S. W. H., Widya, M., Marsusi. 2005. Pertumbuhan, Kandungan Nitrogen, Klorofil dan Karotenoid Daun Gynura procumbens [Lour] Merr. pada Tingkat Naungan Berbeda. Biofarmasi 3(1): 7-10.

Quansah, G.W. 2010. Improving soil productivity through biochar amendments to soils. Africa J. Environ. Sci. and Tech. 3:34-41.

Schmidt. F.H.. and J.H.A. Ferguson. 1951. Rainfall type based on wet and dry periode ratio for Indonesia with Western New Gurinea. Kementerian Perhubungan. Jawatan Meteorologi dan Feofisika. Jakarta. Setyorini, D., R. Saraswati., E.K. Anwar. 2006.
Kompos. Resume buku pupuk hayati pupuk organik. Tersedia: balittanah. litbang.pertanian.go.id.

Siallagan,Irwan, Sudrajat, dan Haryadi.2014. Optimasi dosis pupuk organik dan NPK majemuk pada tanaman kelapa sawit belum menghasilkan. J. Agron. Indonesia $42(2)$ : 166 - 172.

Sitompul, Hendrikson Ferrianto, Toga Simanungkali, Lisa Mawarno. 2014. Respons Pertumbuhan Bibit Kakao (Theobroma cacao L.) Terhadap Pemberianpupuk Kandang Kelinci dan Pupuk Npk (16:16:16). Jurnal Online Agroekoteknologi . Vol.2, No.3 : 1064 - 1071, Juni 2014. 